\title{
The effects of anthropogenic greenhouse gases and aerosols on the inter-decadal change of the South China Sea summer monsoon in the late twentieth century
}

Article

Accepted Version

Lin, Z., Dong, B. and Wen, Z. (2020) The effects of anthropogenic greenhouse gases and aerosols on the interdecadal change of the South China Sea summer monsoon in the late twentieth century. Climate Dynamics, 54 (7-8). pp. 3339-3354. ISSN 0930-7575 doi: https://doi.org/10.1007/s00382-020-05175-9 Available at https://centaur.reading.ac.uk/89223/

It is advisable to refer to the publisher's version if you intend to cite from the work. See Guidance on citing.

To link to this article DOI: http://dx.doi.org/10.1007/s00382-020-05175-9

Publisher: Springer

All outputs in CentAUR are protected by Intellectual Property Rights law, including copyright law. Copyright and IPR is retained by the creators or other copyright holders. Terms and conditions for use of this material are defined in the End User Agreement. 


\section{www.reading.ac.uk/centaur}

\section{CentAUR}

Central Archive at the University of Reading

Reading's research outputs online 
1 The effects of anthropogenic greenhouse gases and aerosols on the inter-decadal change

2 of the South China Sea summer monsoon in the late $20^{\text {th }}$ Century

3 Zhongxi Lin ${ }^{1}$ Buwen Dong2 Zhiping Wen ${ }^{3}$

41 Center for Monsoon and Environment Research/School of Atmospheric Sciences, Sun Yat-sen

5 University, Guangzhou, China

62 Department of Meteorology, National Centre for Atmospheric Science, University of Reading,

7 Reading, UK

83 Department of Atmospheric and Oceanic Sciences \& Institute of Atmospheric Sciences, Fudan

9 University, Shanghai, China

10

19 Corresponding author:

20 Zhongxi Lin,

21 Center for Monsoon and Environment Research/ School of Atmospheric Sciences

22 Sun Yat-Sen University,

23 Zhuhai, 519082 China

24 E-mail: linzhxi@mail2.sysu.edu.cn 
Abstract: Analysis of observational precipitation indicates that in last few decades, the precipitation in boreal summer (June-August) over the South China Sea (SCS) exhibited an interdecadal variation, characterized by a decrease of $0.59 \mathrm{~mm} /$ day from the period 1964 1981 to the period 1994-2011. Accompanied this decrease in precipitation is weakened monsoon circulation featured by an anti-cyclonic circulation anomaly over the SCS in the later period relative to the early period. This work investigates impacts of anthropogenic forcing changes on this interdecadal change in observations, quantify the relative roles of greenhouse gases (GHG) forcing and anthropogenic aerosol (AA) forcing. A set of experiments is designed using the atmospheric component of a state-of-the-art climate model coupled to a multi-level mixed-layer ocean model forced with GHG concentrations and AA emissions in two periods. Modeling results indicate a dominant role of anthropogenic forcing on the observed interdecadal precipitation decrease and weakened monsoon circulation over the SCS in the late $20^{\text {th }}$ century in which AA forcing plays a more important role compared with GHG forcing. The mechanisms of GHG influences and $A A$ induced changes are revealed by individual forcing experiments. Increasing GHG concentrations can suppress convection over the SCS summer monsoon (SCSSM) region by warming the tropical Pacific with an El-Niño like sea surface temperature (SST) pattern, which is associated with a weakened Walker circulation. The changes in AA emissions, mainly through increases in emissions over Asia, lead to cool SST in the north Indian Ocean and the western North Pacific (WNP), and result in changes in meridional SST gradient over the tropical Indian Ocean and the WNP in pre-monsoon seasons. This anomalous meridional SST gradient leads to anomalous local Hadley circulation, characterized by anomalous ascents around the equator and descents over monsoon region, which 
49

50

51

52

53

54

55

56

57

58

59

60

61

62

63

64

65

66

67

68

69

70

71

suppresses convection over the SCS and reduces local precipitation.

Key words: South China Sea summer monsoon, anthropogenic greenhouse gases, anthropogenic aerosols, precipitation.

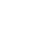

\section{Introduction}

The South China Sea (SCS) locates in Southeast Asia between the equator and South China coast, from $110^{\circ} \mathrm{E}$ to $120^{\circ} \mathrm{E}$. It is in the center of the Asian-Australian monsoon system and has a close relation with the East Asian monsoon, South Asian monsoon and Western North Pacific monsoon due to geographic location (Tao and Chen 1987; Ding 1992, Murakami and Matsumoto 1994; Wang 1994; Lau and Yang 1997). The climate over the SCS is mainly controlled by monsoon circulation, characterized by a warm and wet westerly low-level flow during boreal summer, and cold and dry easterly low-level flow during winter. In summer, westerly flow comes from the Indian Ocean, turns into southerly and transports moisture to the East Asian monsoon region. Over the SCS, this cyclonic circulation forms a local monsoon trough and leads to convection and abundant precipitation.

The SCS summer monsoon (SCSSM) changes in multiple time-scales (Zhou et al. 2005; Wang et al. 2009; Tong et al. 2009) and can be affected by many different factors, including solar radiation on orbital time scale (Prell 2011), interdecadal time scale, and sea surface temperature (SST) variability and land-sea thermal contrast on interannual time scale (Wang and Zhang 2002; Lau et al. 2004; Zhou et al. 2005; Lau and Wang 2006; Yuan et al. 2008; Wang and Qian 2009; Zhu et al. 2011). Its intensity is sensitive to the definition since the SCSSM can be affected by the multiple monsoon subsystems, including the East Asian summer monsoon (EASM), South Asian summer monsoon (SASM), and western North 
Pacific summer monsoon (WNPSM). Previous researches use some indices to describe characteristics of the SCSSM, including its southwesterly low-level flow, local convection and moisture transport convergence (Lu and Chan 1999; Liang et al. 1999; Li and Zhang 1999; Dai et al. 2000; Liang et al. 1999; Wu and Liang 2001; Yao and Qian 2001; Zhang et al. 2002; Wen et al. 2006; Wang et al. 2008). A meridional shear vorticity index (zonal wind in the south SCS minus that in the north SCS; Wang et al. 2009) is created to describe the strength of the SCSSM and is then widely used. Based on 7-year mean of this index, interdecadal changes are observed in the early 1970s and the early 1990s (Wang et al. 2009). However, drivers and physical mechanisms for these interdecadal changes are not fully investigated.

The interdecadal variation of the EASM and SASM has been attributed to both internal variability associated with low frequency SST variability in the Atlantic and Pacific (i.e., the Pacific Decadal Oscillation [PDO] and the Atlantic Multidecadal Oscillation [AMO], Goswami et al. 2006; Lu et al. 2006; Zhou et al. 2009) and external forcing associated with changes in greenhouse gases (GHG) and anthropogenic aerosol (AA) emissions (Song et al. 2014; Li et al. 2015; Li and Ting 2017, Tian et al. 2018, Luo et al. 2019). Most of previous studies agree that precipitation tends to increase in both EASM and SASM due to increased moisture content in the atmosphere with increasing GHG forcings. Despite of the increased moisture content, the effect of GHG and AA on the monsoon circulation is important and requires further research.

The greenhouse gases (GHG) can change the SASM monsoon circulation by changing the large-scale tropical Walker circulations and land-sea thermal contrast (Ueda et al. 2005). In some model studies, the intensity of the Walker circulation connecting the tropical Pacific 
and monsoon region tends to be weakened (Tanaka et al. 2004; Ueda et al. 2005, May 2002, Vecchi and Soden 2006; Lau and Kim 2017), which suppresses the convection in the SASM region. The land-sea thermal contrast is increased as the temperature over land response to GHG increases is stronger than over ocean (Sutton et al. 2007; Dong et al. 2009). The land-sea thermal contrast between South Asia and Indian ocean, which is an important driver of the SASM (Wu et al. 2012), could lead to an enhanced circulation (Hu et al. 2000). However, the weakened thermal contrast in the upper troposphere might play a more important role in a long-term trend and weakened SASM monsoon circulation (Sun et al. 2010). For the EASM, Jiang and Wang (2005) and Song et al. (2014) suggested that the summer monsoon circulation over East Asia is slightly enhanced based on model ensembles. It is further revealed that the increased GHG leads to enhanced western North Pacific Subtropical High (WNPSH) and increased southerly on the western boundary of WNPSH (Tian et al. 2018). Over ocean, Lee et al. (2008) suggested that the low-level convergence decreases over the western North Pacific and the WNPSM weakens despite of increasing moisture in the atmosphere in response to $\mathrm{CO}_{2}$ increases.

Some anthropogenic aerosols (AA) can cause surface cooling by scattering and absorbing solar radiation and change the radiative properties of clouds (Boucher et al. 2013). Meanwhile, black carbon and organic carbon can absorb reflected solar radiation to increase the atmospheric temperature (Menon et al. 2002; Ming et al. 2010; Ramanathan et al. 2001). As AA emissions increased during the last few decades in Asia, it might affect the adjacent precipitation by altering the land-sea thermal contrast and relative monsoon circulation (Ming and Ramaswamy 2011; Rotstayn and Lohmann 2002; Dong et al. 2016). In SASM region, the monsoon circulation changes in response to increased AA emissions are characterized 
by an anomalous meridional overturning circulation that tends to decrease precipitation over the Indian peninsula (Bollasina et al. 2011). Some model studies suggest the resulted anomalous meridional SST gradient over the Indian Ocean with cooling on the North Indian Ocean in response to AA emission changes is the main driver (Ganguly et al. 2012; Ganguly et al. 2012; Ramanathan et al. 2005; Chung et al. 2006; Luo et al. 2019). In EASM region, observations show a wet trend in south China and a drought trend in north in past several decades and this pattern is considered as a result of increased aerosol emissions in China (Wang 2001; Ding et al. 2008, 2009; Menon et al. 2002; Xie et al. 2016; Tian et al. 2018). Some studies suggest that the aerosol can cause a regional cooling over land and leads to a weakened land-sea thermal contrast and thus weakened EASM circulation and precipitation (Ye et al. 2013; Song et al. 2014, Dong et al. 2016).

In Asian monsoon region, GHG and AA do not always play similar roles for the monsoon decadal variations. Lau and Kim (2017) suggested that increases in GHG since 1950s generate an increased land-sea thermal contrast but it is masked by the cooling induced by AA forcing. This study also suggested that the EASM and SASM are having different sensitivity to GHG and AA changes. In EASM region, as the circulation is weakened by AA effect while GHG's role is negligible due to the offset by its dynamic effect and thermodynamic effect, AA forcing is more dominating in the decreased monsoon circulation and tends to reduce the precipitation (Zhang and Li 2016; Song et al. 2014). Luo et al. (2019) suggested that reduction in precipitation in South Asia in last few decades is related to the weakened SASM circulation in response to changes in both GHG and AA and that circulation change induced precipitation decrease is stronger than the increase related to moisture increase in the atmosphere. All above mentioned studies are on changes of GHG 
and AA emissions on either the EASM or SASM. In contrast, the anthropogenic influences on the SCSSM and physical processes involved are not fully investigated.

This study aims to elucidate the processes of how GHG and AA affect the inter-decadal change of the SCSSM in the late $20^{\text {th }}$ century, focusing on: 1) What is the role of anthropogenic forcing to the observed inter-decadal change? 2) What are the relative roles of changes in GHG and AA frocings? 3) What are the physical processes? We have performed a set of model experiments using the atmospheric component of the state-of-theart HadGEM3 global climate model coupled to a multi-level mixed-layer ocean model to address these questions.

Lots of studies about impacts of anthropogenic forcings on the EASM and SASM use full ocean Coupled General Circulation Models (CGCM) including CMIP5 models (Song et al. 2014; Seo et al. 2013; Chen et al. 2016; Sharmila et al. 2015), but these models usually have significant bias on sea surface temperature (SST) in mean state (Li et al. 2012; 2015; Levine et al. 2013). As the Australian-Asian monsoon is sensitive to SST, this bias may cause even larger bias on monsoon simulation. Thus, MetUM-GOML models use an ocean mixed-layer model replacing the 3D CGCMs, which can reduce the calculation cost and have a smaller SST bias by a prescribed flux corrections (Hirons et al. 2015, Dong et al. 2017, Tian et al. 2018). So, this work will use a set of experiments based on the second generation of GOML models (MetUM-GOML2).

The structure of this paper is as follows: Section 2 analyses the observational data and describes the inter-decadal change of the SCSSM in the late $20^{\text {th }}$ century. Section 3 introduces the model and detailed design of model experiments. Section 4 evaluates the relative contributions of different forcings to the inter-decadal change. Sections 5 and 6 
reveal the physical processes of changing GHG or AA forcing on the SCSSM respectively. Finally, our conclusions are drawn in Section 7.

\section{Observed inter-decadal change}

In this study, we use monthly NOAA's Precipitation Reconstruction (PREC) dataset (Chen et al. 2002) and precipitation based on GPCP (Adler et al. 2003). Observed 3D monthly horizontal velocity and vertical velocity come from NCEP Reanalysis 1 (NCEP1; Kalnay et al. 1996) while monthly sea level pressure (SLP) is obtained from Hadley Centre Sea Level Pressure dataset (HadSLP2; Allan and Ansell 2006). All variables are averaged from June to August to describe the boreal summer mean.

To show the inter-decadal variability (IDV) of rainfall change in observations, the area averaged precipitation in the South China Sea region $\left(10^{\circ} \mathrm{N}-20^{\circ} \mathrm{N}, 105^{\circ} \mathrm{E}-120^{\circ} \mathrm{E}\right)$ in $\mathrm{JJA}$ is defined as an index and its time evolution is shown in Figure 1a. One of the most important features of the time evolution of this precipitation index is the inter-decadal variation across the 1990s, characterized by a positive precipitation anomaly from 1964 to 1981 (early period, EP) and a negative precipitation anomaly from 1994 to 2011 (present day, PD). These periods are selected also to avoid the impact of volcanic eruptions. The mean anomaly in these two periods is $0.45 \mathrm{~mm} /$ day in EP and $-0.14 \mathrm{~mm} /$ day in $\mathrm{PD}$, respectively, which means a $-0.59 \mathrm{~mm} /$ day (which is about $13.6 \%$ of the climatological mean of $1979-2018$ in GPCP dataset) decrease from EP to PD.

We compare the spatial pattern of precipitation and circulation associated with this interdecadal change (PD minus EP) to understand the physical processes involved. It is found that the inter-decadal decrease in precipitation mainly centered in the SCS (up to 0.5-2.0 
$\mathrm{mm} /$ day), and was accompanied by anomalous anticyclonic circulation in the lower troposphere (fig. 1b) with anomalous easterlies across the SCS. The anomalous easterlies over the SCS indicate weakened climatological SCS westerlies in the summer from EP to PD. The anomalous anticyclonic circulation is also associated with anomalous divergence in the lower troposphere and anomalous convergence in the upper troposphere (Fig. 1c) with anomalous descent in the whole troposphere (Fig. 1d), indicating weakened convection in the SCS and therefore leading to reduced precipitation.

What had caused this inter-decadal decrease in precipitation and monsoon circulation over the SCS seen in observations? To find out drivers and understand the dynamical mechanisms behind it, we perform a set of time slice experiments with the atmospheric component of the state-of-the-art HadGEM3 global climate model coupled to a multi-level mixed-layer ocean model with changes in GHG and AA emissions together from EP to PD or changes in GHG and AA forcing separately.

\section{Models and experiments}

\subsection{MetUM-GOML2 model and experiments settings}

In this work, MetUM-GOML2 (e.g., Hirons et al. 2015) is used to perform a set of experiments. The atmospheric component of the MetUM-GOML2 is the Met Office Unified Model (MetUM) at the fixed scientific configuration Global Atmosphere 6.0 (GA6.0) with N96 horizontal resolution $\left(1.875^{\circ}\right.$ longitude and $1.25^{\circ}$ latitude) and 85 vertical levels. A detailed description of GA6.0 is given by Walters et al. (2017). The atmospheric model includes an interactive tropospheric chemistry scheme (eight aerosol species are included: ammonium sulphate, mineral dust, fossil fuel black carbon, fossil-fuel organic carbon, biomass-burning, 
ammonium nitrate, sea-salt, and secondary organic aerosols from biogenic emissions. Both aerosol-radiation interaction and aerosol-cloud interaction (including aerosol indirect effect and semi-indirect effect) are considered. More details about the parameterization of aerosol indirect effect are described by Jones et al. (2011) and Bellouin et al. $(2011,2013)$.

The oceanic component is a Multi-Column K Profile Parameterization mixed-layer ocean model. The horizontal resolution of MC-KPP is the same as AGCM where they are coupled, and below each AGCM grid point in ocean region is one water column. The atmospheric and oceanic components are coupled every 3 hours. Since MC-KPP only simulate vertical mixing in each grid point and exclude the ocean dynamics, the climatological seasonal ocean 3D flux corrections are applied on ocean temperature and salinity (Large et al. 1994). These corrections are intended to represent the mean advection in ocean and account for biases in atmospheric surface fluxes.

The set of experiments used in this study is the same as those used to investigate SASM decadal changes in Luo et al. (2019). Here, we use greenhouse gases (GHG) and anthropogenic aerosol (AA) forcings averaged over 1994-2011 as PD conditions. For EP forcing, GHG forcing is an average of $1964-1981$ while AA forcing is an average of $1970-$ 1981. The details of experiments are summarized in Table 1. Firstly, a relaxation experiment is run for 12 years (E0) forced by PD GHG and AA forcing. In this experiment, the MC-KPP profiles of temperature and salinity were relaxed to a PD climatological ocean temperature and salinity from the Met Office ocean analysis data (Smith and Murphy 2007). Then we diagnosed the seasonal cycle of climatological daily-mean 3D ocean temperature and salinity corrections from E0. These temperature and salinity are the same and are imposed in all free running coupled experiments. Therefore, response in the model experiments to a 
particular forcing change includes both the fast response to the forcing change (i.e. surface and atmospheric process) and slow response mediated by forcing induced SST change.

235 For free coupled experiments, the EP experiment (EP) is forced by GHG and AA forcing of EP while All forcing present day (PD-ALL) is forced by PD GHG and AA forcing. In addition, two extra experiments, present-day GHG forcing (PD-GHG) with PD GHG but EP AA and present-day AA forcing (PD-AA) with PD AA but EP GHG, that are used to analyze the individual effect of GHG and AA. All coupled experiments are run for 60 years and only last 55 years of each experiment are used for analysis. In all experiments, the annual mean concentrations of GHG are prescribed uniformly globally while the aerosol emissions include seasonal cycle and spatial distribution. The spatial distribution of changes in annual mean sulphur dioxide emissions between the two periods was illustrated in the Fig. 3 in Chen and

Dong (2019) where changes are characterized by decreases over North America and Europe and increases over South Asia and East Asia.

The response of different forcing is estimated by the difference of climatology between

247 a pair of experiments. The difference of PD-ALL and EP represent the combine effect of 248 GHG and AA forcing difference, while PD-GHG minus EP and PD-AA minus EP are estimation of individual effect of GHG forcing and AA forcing. The statistical significance of the difference in a pair of models is assessed using a two tailed Student's t-test.

\subsection{Model climatology}

In this section, some climatological features of PD experiment are compared with observations. Fig.2a and b show the precipitation, SLP and $850 \mathrm{hPa}$ wind from June to 
wind from NCEP reanalysis 1 and observed precipitation from Global Precipitation

257 Climatology Project (GPCP; Adler et al. 2003). In observations, spatial pattern of SLP is 258 characterized by low SLP over the Eurasia continent and high SLP on the tropical Indian ocean and western North Pacific (WNP). This SLP distribution is associated with westerly monsoon flow from India and it turns into southwesterly with cyclonic circulation over the SCS, known as the monsoon trough. This westerly monsoon flow transports a large amount of water vapor to the SCS and leads to moisture convergence there associated with the cyclonic flow, inducing convection and producing large precipitation in the region. sea contract of SLP are well reproduced by GOML2 model. However, the westerly from the Indian Ocean is stronger in the model due to the overestimated meridional land-sea SLP contrast. Thus, the westerly wind and monsoon trough extend eastward into the WNP in the model and the simulated precipitation in the monsoon trough is larger than in observations. low-level circulation over East Asia and adjacent regions well compared with observations, which suggests this model can be an appropriate tool to study the precipitation change over the SCS in response to different forcings.

277 to changes in both GHG and AA forcings are shown in Fig.3a. Model simulated responses 278 to changes in anthropogenic forcing from EP to PD are characterized by anomalous 
easterlies from the WNP, across the SCS, into the Indian peninsula, indicating a weakening of climatological westerlies. The weakened westerlies are associated with reduced precipitation in latitude band of $\left(10^{\circ} \mathrm{N}-20^{\circ} \mathrm{N}\right)$ and increased precipitation to the south. These features in the model simulations are similar to observed inter-decadal changes between PD and EP in observations (Fig.1b), indicating that the changes in anthropogenic forcing might have played a dominant role in the observed inter-decadal changes of the SCSSM and reduced precipitation over the SCS in the late $20^{\text {th }}$ century.

Shown in Fig. 3 b and c are model simulated changes in response to either changes in GHG or AA forcing. The patterns of large-scale circulation and precipitation in response to changes in AA forcing (Fig. 3c) are similar to changes in ALL forcing experiment (Fig. 3a). Although precipitation under GHG forcing reduces as well, the easterly anomaly over the SCS region is weak. These responses to individual forcing change indicate that model simulated weakening of the SCSSM and reduced precipitation over the SCS from EP to PD are predominantly due to changes in AA forcing (Fig.3a, c) with weak contributions from changes in GHG (Fig. 3b).

To investigate the processes that contribute to the precipitation changes in the model simulated responses to different forcings, the column integrated moisture flux transports and their convergences are shown in Fig.4. The moisture flux transports and their convergences are further decomposed into a dynamic component due to circulation change and a thermodynamic component due to humidity change (e.g., Li and Ting 2017, Tian et al. 2018). In many aspects, the patterns of changes in moisture flux convergences and their magnitudes in response to different forcings (Fig. 4a, d, g) are similar to changes in model simulated precipitation responses (Fig. 3). This indicates that it is the moisture flux 
convergence responsible for model simulated precipitation changes. However, changes in dynamic components and thermodynamics components show some different features in response to different forcings. In response to ALL forcing change, the dynamic components (Fig.4b) show anomalous westward moisture flux transport and anomalous moisture transport divergence from the WNP, across the SCS, into the SASM region. These anomalies in dynamic components are partially offset by anomalous eastward moisture transports and convergences due to thermodynamic components related to warming mainly induced by changes in GHG (this will be discussed in section 5). In response to changes in GHG forcing, the model simulated moisture convergence changes (Fig.4d) are weak over the SCS due to compensation between the dynamic component related to weakened circulation (Fig.4e) and thermodynamic component related to increased water vapor in the atmosphere (Fig. 4f). In response to changes in AA forcing, the changes in moisture flux transports and their divergences are predominantly due to dynamic components related to circulation changes with weak contribution from changes in humidity (Fig. $4 \mathrm{~g}, \mathrm{~h}$, and i).

To quantify the regional precipitation changes over the SCS, area averaged precipitation changes in observations and model simulated changes in response to different forcings are shown in Figure 5a. ALL forcing change leads to a decrease in precipitation by $0.32 \mathrm{~mm} /$ day and contributes approximately $72 \%$ of observed inter-decadal decrease $(-0.44 \mathrm{~mm} / \mathrm{day})$, suggesting anthropogenic forcing changes from EP to PD might have been a dominating effect for observed inter-decadal decrease in precipitation in the late $20^{\text {th }}$ century. Individual forcing both have a positive contribution on precipitation decrease with a dominant contribution from changes in AA forcings. The regional averaged moisture transport convergence is shown in Figure 5c. As the total moisture transport convergence shows a 
similar change as precipitation in Fig.5a, the dynamic and thermodynamic components clearly show how anthropologic forcings change circulation and humidity, and contribute to the interdecadal deceased precipitation. All forcing, GHG forcing and AA forcing result in weakened dynamic moisture transport convergence. However, as GHG changes warm the atmosphere significantly, the thermodynamic part of all forcing and GHG forcing increases and this offsets the dynamic component partially. AA emission changes do not change the humidity much, so the thermodynamic component in AA forcing is weak and the weakened total moisture transport convergence is predominantly related to changes in circulation. It should be noted a nonlinearity of changes in the SCSSM in response to changes in GHG and AA emissions (i.e., the response to the combined forcings is not necessarily equal to the sum of the responses to the individual forcings). In particular, the sum of precipitation changes over the SCS in response to GHG and AA changes is larger than the change in response to ALL forcing. The nonlinearity noticed in this study is consistent with some previous studies (Feichter et al. 2004, Ming and Ramaswamy 2009, Shiogama et al. 2012). However, detailed investigation of the causes in this nonlinearity is beyond the scope of this study.

The regional averaged zonal wind components over southern SCS $\left(5^{\circ} \mathrm{N}-15^{\circ} \mathrm{N}, 105^{\circ} \mathrm{E}-\right.$ $120^{\circ} \mathrm{E}$ ) are shown in Fig.5b. In observations and model experiments, zonal wind in this region change most significantly. This figure further illustrates that the weakened precipitation over the SCS in response to changes in anthropogenic forcing (ALL forcing) is mainly contributed by the weakened zonal wind and reduced moisture transports, and the response to AA forcing plays a dominant role. In summary, it has demonstrated that the circulation and precipitation changes in response to changes in individual GHG or AA forcing 
show different characteristics. Thus, in the next two sections, we are exploring physical processes that are responsible for the large-scale circulation differences in response to individual forcing respectively.

\section{Mechanism related to GHG forcing}

The model simulated precipitation changes under GHG forcing show some weak decreases, mainly resulted from the moisture flux transport compensation between the dynamic component related to weakened circulation and thermodynamic component related to increased humidity. What processes are responsible for the circulation and humidity changes in the model simulations?

In GHG forcing experiment, large scale anomalous descends cover a large area including the SASM region and the SCS region, accompanied by a low-level easterly anomaly (Fig.3b). These anomalous local circulation anomalies and descents are associated with anomalous large-scale divergent circulations in the tropical Indian and Pacific oceans (Fig. 6). These anomalous large-scale circulations indicate anomalous convergence over the tropical eastern Pacific in the lower troposphere and anomalous divergence in the upper troposphere with opposite changes over the tropical Indian ocean and the western tropical Pacific, being associated with weakened Walker circulation. Associated with these large-scale divergent circulations are that SST warming is stronger in the eastern tropical Pacific (over $0.5^{\circ} \mathrm{C}$ ) than western tropical Pacific (about $0.3^{\circ} \mathrm{C}$ ) (Fig. $7 \mathrm{~b}$ ), indicating a weakening zonal SST gradient in the tropical Pacific. This association between the change in zonal SST gradient and large scale divergent circulations is consistent with previous researches which suggested that the zonal SSTA gradient change associated with 
371 El-Nino like SST anomalies enhances convection over the eastern equatorial Pacific and 372 leads to a weakened Walker circulation over the tropics (Ju and Slingo 1995; Timmermann 373 et al. 1999; Wilhelm, 2002).

How do changes in GHG forcing lead to enhanced warming over the eastern tropical Pacific than in western tropical Pacific? Firstly, GHG forcing changes surface radiation balance. With increase in GHG forcing, both clear sky surface longwave radiation (clear-sky LW) and surface longwave cloud radiative effect (CRE-LW) increase over the equatorial Pacific (Fig.7c and 7d). Because mixed layer depth is deeper in the western tropical Pacific than in the eastern tropical Pacific, the response of SSTA is weaker in the west and stronger in the east. This zonal asymmetry leads to a weakened zonal SST gradient and Walker circulation through the dynamic processes elucidated above. This mechanism agrees with previous research (DiNezio et al. 2009; Yeh et al. 2009; Collins et al. 2010) which revealed the relationship of climate change, EI-Nino like SSTA change and relative trade wind change. Secondly, as air temperature increases due to increasing GHG concentrations, atmosphere can hold more moisture over the SCS. Warmer sea surface temperature can also increase the evaporation locally so both these changes lead to increase in the water vapor in the atmosphere (Fig.7a). circulation over the SCS in GHG forcing experiments are caused by anomalous descend which is related to weakened Walker circulation.

\section{Mechanism related to AA forcing}


divergences are predominantly due to dynamic components related to circulation changes with weak contribution from changes in humidity (Fig. 4g, h, i). In AA forcing experiment, there are significant easterly anomalies over the monsoon region from the Arabian Sea to the western North Pacific (Fig. 3c).

To understand the mechanism of these circulation changes, we analyze the zonal mean $\left(60^{\circ} \mathrm{E}-150^{\circ} \mathrm{E}\right)$ meridional overturning circulation changes in response to AA forcing (Fig.8a). These anomalous overturning circulations are characterized by anomalous descents around monsoon region $\left(10^{\circ} \mathrm{N}-25^{\circ} \mathrm{N}\right)$ and anomalous ascends around the equator, indicating a change in local Hadley circulation. Previous researches suggest that this anomalous local Hadley circulation might be a result of SSTA meridional gradient (Ganguly et al. 2012; Ganguly et al. 2012; Ramanathan et al. 2005; Chung et al. 2006; Luo et al. 2019). However, the SSTA gradient change in JJA is weak in response to AA forcing (Fig. 8b). The SSTA over ascend region is about $-0.05^{\circ} \mathrm{C}$ and it is about $0^{\circ} \mathrm{C}$ over descend region (Fig8b). This association between anomalous ascents (descents) with anomalous cold (weak) SST seems counterintuitive. However, this simultaneous association includes atmospheric feedbacks on SST changes. Thus, we explore the SSTA in pre-monsoon seasons (Fig.9). There is no significant SSTA over the northern Indian Ocean (NIO) and the SCS in JJA, but during December to February (DJF) and March to May (MAM), SST is cooled to the north of the equator in this region (about $-0.1^{\circ} \mathrm{C}$ to $-0.3^{\circ} \mathrm{C}$ ). This meridional SST gradient in premonsoon seasons is key processes for local Hadley circulation anomaly in JJA.

To understand the process of how aerosol changes affect SSTA and circulation in the pre-monsoon seasons, seasonal evolutions of zonal averaged changes over the monsoon region $\left(60^{\circ} \mathrm{E}-150^{\circ} \mathrm{E}\right)$ are analyzed and they are illustrated in Fig. 10. Results indicate that 
large summer monsoon precipitation and circulation changes occur in June and become weaker in July and August (Fig.10a and 10b). The meridional SSTA gradient with relative large cold anomalies of about $0.2^{\circ} \mathrm{C}$ in the northern subtropics sustains during pre-monsoon seasons until it gets weaker after May and June when monsoon establishes (Fig.10c). This SSTA pattern and associated meridional SST gradient (cooler in north than in south) sustains until May and June when it drives a local Hadley circulation which causes an anomalous descend over monsoon region and then weakened westerly low-level flow and less precipitation.

This SSTA annual cycle is driven by surface radiation changes. In response to AA forcing, clear-sky surface shortwave radiation (clear-sky SW) decreases all year round over the ocean with maximum changes during SON and MAM (Fig.10d), which cause a cooler SSTA locally. The clear-sky SW changes are closely related to the aerosol-radiation interaction and aerosol-cloud interaction. Changes in aerosol optical depth (AOD), cloud droplet effective radius (CDER) and cloud droplet number (CDN) are larger over the NIO and the SCS in pre-monsoon seasons (largest during SON) than in JJA since aerosol emissions are advected by the prevailing winds to these regions (Fig.11j-11i). These changes are characterized by increases in AOD, decreases in CDER, and increases in CDN. Note that seasonal changes in CDER show some differences in comparison with changes in AOD and CDN since CDER-CDN relationship is not linear (Jones et al. 2001) and CDER change is more sensitive to the basic state environment than CDN over ocean where the atmosphere is cleaner (Carslaw et al. 2013). These changes in AOD, CDN, and CDER are responsible for the seasonal evolutions of changes in surface clear sky SW and SST (Fig. 10c, d). As a result, the SSTA is cool over the NIO to equatorial IO since SON and sustains 
until May and Jun.

In May and June, the SST is still cooler over the NIO than around the equator, which drives a local Hadley circulation. However, upward surface latent heat flux reduces related to weakened low-level westerlies (anomalous easterlies) over monsoon region (positive downward in Fig.10e). Meanwhile shortwave cloud radiative effect shows positive changes (CRE-SW, Fig.10f) due to less cloud cover associated with reduced convection. These feedbacks associated with the changes in circulation and surface radiation damp cold SST anomalies induced by AA change in pre-monsoon seasons, leading to weak SST anomalies in JJA and weak meridional SST gradient.

In summary, when changes in AA emissions are advected by prevailing winds from the Asian continent to the NIO and the SCS in pre-monsoon seasons, the SST is cooled by reduced clear sky SW while changes in both clear sky SW radiation and SST are weak in the southern hemisphere. These result in anomalous meridional SST gradient in Asian sector and this meridional SST gradient sustains until boreal summer, which in turn drives weakened monsoon circulation and precipitation over the SCS in summer. In May and June when precipitation is reduced, the SST warms over the NIO due to increased shortwave cloud radiative effect (Fig. 10f) related to reduced cloud cover and weakened latent heat flux (Fig. 10e) related to weakened westerlies. These processes tend to damp cold SST anomalies in pre-monsoon seasons lead to weak summer mean SST anomalies over the NIO (Fig.9d, Fig. 10c).

\section{Conclusion and discussion}

Base on observations, there is a significant inter-decadal decrease of precipitation over 
the SCS between 1964-1981 and 1994-2011 during boreal summer monsoon season (JJA). Corresponding to the change in precipitation is a weakened SCSSM circulation, characterized by anomalous descend over the SCS, weaker westerly monsoon flow in the lower troposphere and less moisture flux transport convergence to the SCSSM region. In this study, a set of experiments based on MetUM-GOML2 model is used to investigate the role of anthropogenic forcing (including GHG and AA emission) changes and quantify the relative roles of GHG and AA forcing, on the inter-decadal decrease of the SCSSM and precipitation. The main results are summarized as follows:

1. Model results suggest that the changes in anthropogenic forcing from EP (19641981) to PD (1994-2011) might have played a dominant role in the observed inter-decadal changes of the SCSSM and reduced precipitation in the late 20th century in which AA forcing plays a more important role compared with GHG forcing.

2. Increased GHG concentrations lead to positive changes in surface longwave radiation over the tropical Pacific. Due to the asymmetric mixed layer depth, warming in the eastern equatorial Pacific is greater than in the western tropical Pacific. This El-Niño-like SSTA pattern leads to a weaker Walker circulation and causes a large-scale descend in both Indian monsoon and SCS monsoon region, and causes a weaker westerly low-level flow. This weakened monsoon circulation leads to weakened moisture flux transport convergence and therefore reduced precipitation over the SCS. Meanwhile, the warm SST anomalies lead to increases of evaporation and the water vapor in the atmosphere. This leads to increased moisture flux transport convergence and therefore enhanced precipitation over the SCS. Due to this compensation between dynamical moisture transport and thermodynamic moisture transport, the changes in moisture transport convergence, and 
therefore precipitation over the SCS are weak.

3. In response to changes in AA emissions, $C D N$ and $A O D$ increase while CDER decreases over continental Asia due to increased AA emissions over Asia. In pre-monsoon seasons, aerosol emissions are transported to the northern Indian Ocean and the SCS by prevailing winds, leading to increases in CDN and AOD and decreases in CDER in these regions. These changes lead to reduced surface clear-sky shortwave radiation in the northern subtropics with weak changes in southern hemisphere. As a result, the SST in the northern subtropics decreases by about $0.2^{\circ} \mathrm{C}$ in pre-monsoon seasons and this cold anomaly sustains until the establishment of summer monsoon. This nonuniform SST change leads to a meridional SST gradient which in turn induces a local Hadley circulation change with anomalous descending at monsoon region and the anomalous easterly wind in the lower troposphere which transport less moisture to the SCS monsoon region, leading to reduced precipitation.

Our modelling results suggest that changes in GHG concentrations and AA emissions might have played an important role in decreased SCSSM and reduced precipitation on the SCS in the late $20^{\text {th }}$ century in which AA forcing plays a more important role compared with GHG forcing. This result is in agreement to some previous researches about role of $A A$ changes in the East Asian summer monsoon based on CMIP5 models (Song et al. 2014; Zhang and Li 2016 ) .

Although the observed inter-decadal decrease of SCSSM precipitation can be captured by this model, it should be pointed out that these results and processes are based on this specific model and experiment design. For example, these experiments use GHG and AA forcing of two specific periods (1964-1981 and 1994-2011) and the ocean model is a mixed 

layer model. Therefore, the role of ocean dynamics are not included in our experiments. In 510 the future, the reliability of the physical processes in this study can be tested by comparing 511 with other models' results which consider the oceanic circulation changes in response to 512 different forcings. In addition, it should be noted a nonlinearity of changes in the SCSSM in 513 response to changes in GHG and $A A$ emissions (i.e., the response to the combined forcings 514 is not necessarily equal to the sum of the responses to the individual forcings). The 515 nonlinearity noticed in this study is consistent with some previous studies (Feichter et al. 516 2004, Ming and Ramaswamy 2009, Shiogama et al. 2012), and needs to be investigated 517 further.

Acknowledgement

This research is jointly supported by the National Key Research and Development 521 Projects of China (2016YFA0600601), the National Natural Science Foundation of China 522 (41530530, 41875087). ZXL were supported by oversea exchange study and cooperative 523 research project 2019 for PhD student in Sen Yat-Sen University (SYSU). BD is supported 524 by the U.K. National Centre for Atmospheric Science-Climate (NCAS-Climate) at the 525 University of Reading. The authors like to thank two anonymous reviewers for their 526 constructive comments and suggestions on the earlier version of the paper. 
Reference:

Adler RF, Huffman GJ, Chang A, et al (2003) The Version-2 Global Precipitation Climatology Project (GPCP) Monthly Precipitation Analysis (1979-Present). J Hydrometeorol. doi: 10.1175/1525-7541(2003)004<1147:tvgpcp>2.0.co;2

Allan R, Ansell T (2006) A new globally complete monthly historical gridded mean sea level pressure dataset (HadSLP2): 1850-2004. J Clim. doi: 10.1175/JCLI3937.1

Bellouin N, Mann GW, Woodhouse MT, et al (2013) Impact of the modal aerosol scheme GLOMAP-mode on aerosol forcing in the hadley centre global environmental model. Atmos Chem Phys. doi: 10.5194/acp-13-3027-2013

Bellouin N, Rae J, Jones A, et al (2011) Aerosol forcing in the Climate Model Intercomparison Project (CMIP5) simulations by HadGEM2-ES and the role of ammonium nitrate. J Geophys Res Atmos. doi: 10.1029/2011JD016074

Bollasina MA, Ming Y, Ramaswamy V (2011) Anthropogenic Aerosols and the Summer Monsoon. Science (80- ) 334:502-505

Boucher O, Randall D, Artaxo P, Bretherton C, Feingold G, Forster P, Zhang X (2013) Clouds and aerosols. In: Stocker T et al (eds) Climate change 2013: the physical science basis. Contribution of working group I to the fifth assessment report of the intergovernmental panel on climate change. Cambridge University Press, Cambridge, pp 571-657

Carslaw KS, Lee LA, Reddington CL, Pringle KJ, Rap A, Forster PM, Mann GW, Spracklen DV, Woodhouse MT, Regayre LA, Pierce JR (2013) Large contribution of natural aerosols to uncertainty in indirect forcing. Nature 503:67-71

Charlson RJ, Schwartz SE, Hales JM, et al (1992) Climate forcing by anthropogenic aerosols. Science (80- ). doi: 10.1126/science.255.5043.423

Chen L and O. W. Frauenfeld (2016) A comprehensive evaluation of precipitation simulations over China based on CMIP5 multimodel ensemble projections. J Geophys 
Chen M, Xie P, Janowiak JE, Arkin PA (2002) Global Land Precipitation: A 50-yr Monthly Analysis Based on Gauge Observations. J Hydrometeorol. doi: 10.1175/15257541(2002)003<0249:glpaym>2.0.co;2

Chen W, and Dong B (2019) Anthropogenic impacts on recent decadal change in temperature extremes over China: Relative roles of greenhouse gases and anthropogenic aerosols. Climate Dyn. 52, 3643-3660, doi: 10.1007/s00382-018-43429.

Chung CE, Ramanathan V (2006) Weakening of north Indian SST gradients and the monsoon rainfall in India and the Sahel. J Clim. doi: 10.1175/JCLI3820.1

Collins M, An S II, Cai W, et al (2010) The impact of global warming on the tropical Pacific Ocean and El Nĩo. Nat Geosci 3:391-397. doi: 10.1038/ngeo868

Dai N, Xie A, Zhang Y (2000) Interannual and Interdecadal Variations of Summer Monsoon Activities over South China Sea[J]. Climatic and Environmental Research(in Chinese),5(4):363-374,doi:10.3878/j.issn.1006-9585.2000.04.04.

Ding Y (1992) Summer monsoon rainfall in China. J. Meteorol. Soc. Jpn. 70, 373-396

Ding Y, Sun Y, Wang Z, et al (2009) Inter-decadal variation of the summer precipitation in China and its association with decreasing Asian summer monsoon Part II: Possible causes. Int J Climatol 29:1926-1944. doi: 10.1002/joc.1759

Ding Y, Wang Z, Sun Y (2008) Inter-decadal variation of the summer precipitation in East China and its association with decreasing Asian summer monsoon. Part I: Observed evidences. Int J Climatol. doi: 10.1002/joc.1615

DiNezio PN, Clement AC, Vecchi GA, et al (2009) Climate response of the equatorial pacific to global warming. J Clim 22:4873-4892. doi: 10.1175/2009JCLI2982.1

Dong B, Gregory JM, Sutton RT (2009) Undestanding land-sea warming contrast in response to increasing greenhouse gases. Part I: Transient adjustment. J Clim 
583

584

585

586

587

588

589

590

591

592

593

594

595

596

597

598

599

600

601

602

603

604

605

606

607

Dong B, Sutton RT, Highwood EJ, Wilcox LJ (2016) Preferred response of the East Asian summer monsoon to local and non-local anthropogenic sulphur dioxide emissions. Clim Dyn 46:1733-1751. doi: 10.1007/s00382-015-2671-5

Feichter J, Roeckner E, Lohmann U, Liepert B (2004) Nonlinear aspects of the climate response to greenhouse gas and aerosol forcing. J Clim 17:2384-2398

Ganguly D, Rasch PJ, Wang H, Yoon JH (2012a) Fast and slow responses of the South Asian monsoon system to anthropogenic aerosols. Geophys Res Lett 39:1-5. doi: 10.1029/2012GL053043

Ganguly D, Rasch PJ, Wang H, Yoon JH (2012b) Climate response of the South Asian monsoon system to anthropogenic aerosols. J Geophys Res Atmos 117:1-20. doi: 10.1029/2012JD017508

Goswami B, Madhusoodanan M, Neema C, Sengupta D (2006) A physical mechanism for North Atlantic SST influence on the Indian summer monsoon. Geophys Res Lett 33, L02706. doi: 10.1029/2005GL024803

Guo L, Highwood EJ, Shaffrey LC, Turner AG (2013) The effect of regional changes in anthropogenic aerosols on rainfall of the East Asian Summer Monsoon. Atmos Chem Phys. doi: 10.5194/acp-13-1521-2013

Held IM, Soden BJ (2006) Robust responses of the hydrologic cycle to global warming. J Clim. doi: 10.1175/JCLI3990.1

Hu ZZ, Latif M, Roeckner E, Bengtsson L (2000) Intensified Asian summer monsoon and its variability in a coupled model forced by increasing greenhouse gas concentrations. Geophys Res Lett 27:2681-2684. doi: 10.1029/2000GL011550

JIANG D and Wang H (2005) Natural interdecadal weakening of East Asian summer monsoon in the late 20th century. Chinese Sci Bull 50:1923. doi: 10.1360/982005-36

Jones A, Roberts DL, Woodage MJ, Johnson CE (2001) Indirect sulphate aerosol forcing in 
a climate model with an interactive sulphur cycle. J Geophys Res 106 D17: 20,29320,310

610

Jones CD, Hughes JK, Bellouin N, et al (2011) The HadGEM2-ES implementation of CMIP5 centennial simulations. Geosci Model Dev. doi: 10.5194/gmd-4-543-2011

Ju J, Slingo J (1995) The Asian summer monsoon and ENSO. Q J R Meteorol Soc. doi: 10.1002/qj.49712152509

Kalnay E, Kanamitsu M, Kistler R, et al (1996) The NCEP/NCAR 40-year reanalysis project. Bull Am Meteorol Soc. doi: 10.1175/1520-0477(1996)077<0437:TNYRP>2.0.CO;2

Lamarque JF, Bond TC, Eyring V, et al (2010) Historical (1850-2000) gridded anthropogenic and biomass burning emissions of reactive gases and aerosols: Methodology and application. Atmos Chem Phys. doi: 10.5194/acp-10-7017-2010

Lau NC, Ann MJ, Wang H (2005). Simulations by a GFDL GCM of ENSO-related variability of the coupled atmosphere-ocean system in the East Asian Monsoon region. East Asian Monsoon.

Lau NC., Wang B. (2006) Interactions between the Asian monsoon and the El Niño/Southern Oscillation. In: The Asian Monsoon. Springer Praxis Books. Springer, Berlin, Heidelberg

Lau KM, Kim KM (2017) Competing influences of greenhouse warming and aerosols on Asian summer monsoon circulation and rainfall. Asia-Pacific J Atmos Sci 53:181-194. doi: $10.1007 / \mathrm{s} 13143-017-0033-4$

Lau KM, Yang S (1997) Climatology and interannual variability of the Southeast Asian summer monsoon. Adv Atmos Sci. doi: 10.1007/s00376-997-0016-y

Lee SM, Jhun JG, Kwon M, Kim W (2008) Change in the western North Pacific summer monsoon circulation due to the $\mathrm{CO}_{2}$ increase in IPCC AR4 CGCMs. Asia Pac J Atmos Sci 44(4):351-368

Levine RC, Turner AG, Marathayil D, Martin GM (2013) The role of northern Arabian Sea surface temperature biases in CMIP5 model simulations and future projections of Indian 
Li C, and Zhang L, (1999) Summer monsoon activities in the South China Sea and its 636 impacts. Chin. J. Atmos. Sci., 23, 257-266.

Li G, Xie SP (2012) Origins of tropical-wide SST biases in CMIP multi-model ensembles. Geophys Res Lett 39:1-5. doi: 10.1029/2012GL053777

Li G, Xie SP, Du Y (2015) Monsoon-induced biases of climate models over the tropical 640 Indian Ocean. J Clim 28:3058-3072. doi: 10.1175/JCLI-D-14-00740.1

Li J, Wu Z, Jiang Z, He J (2010) Can global warming strengthen the East Asian summer monsoon? J Clim. doi: 10.1175/2010JCLI3434.1

Li X, Ting M (2017) Understanding the Asian summer monsoon response to greenhouse warming: the relative roles of direct radiative forcing and sea surface temperature change. Clim Dyn. doi: 10.1007/s00382-016-3470-3

Li X, Ting M, Li C, Henderson N (2015) Mechanisms of Asian Summer Monsoon Changes in Response to Anthropogenic Forcing in CMIP5 Models*. J Clim. doi: 10.1175/jcli-d14-00559.1

Li Z, Lau WKM, Ramanathan V, et al (2016) Aerosol and monsoon climate interactions over Asia. Rev. Geophys.

Liang J, Wu S, and You J, (1999) The research on variations of onset time of the SCS summer monsoon and its intensity. Chin. J. Trop. Meteor., 15, 97-105.

Lu E. and Chan J, (1999) A Unified Monsoon Index for South China. J. Climate, 12, 23752385, doi: 10.1175/1520-0442(1999)012<2375:AUMIFS>2.0.CO;2

Lu R, Dong B, Ding H (2006) Impact of the Atlantic Multidecadal Oscillation on the Asian summer monsoon. Geophys Res Lett 33:1-5. doi: 10.1029/2006GL027655

Luo F, Dong B, Tian F, Li S (2019) Anthropogenically Forced Decadal Change of South Asian Summer Monsoon Across the Mid-1990s. J Geophys Res Atmos 124:806-824. doi: 10.1029/2018JD029195 
Murakami T., Matsumoto J. (1994). Summer monsoon over the Asian continent and western north Pacific. J. Meteorol. Soc. Jpn. 72, 719-745.

May W (2002) Simulated changes of the Indian summer monsoon under enhanced greenhouse gas conditions in a global time-slice experiment. Geophys Res Lett. doi: 10.1029/2001GL013808

Menon S, Hansen J, Nazarenko L (2002) Climate Effects of Black Carbon Aerosols in China and India. 297:2250-2254

Ming Y, Ramaswamy V (2009) Nonlinear climate and hydrological responses to aerosol effects. J Clim 22:1329-1339

Ming Y, Ramaswamy V, Persad G (2010) Two opposing effects of absorbing aerosols on global-mean precipitation. Geophys Res Lett 37:1-4. doi: 10.1029/2010GL042895

Ming Y, Ramaswamy V (2011) A model investigation of Aerosol-Induced changes in tropical circulation. J Clim. doi: 10.1175/2011JCLI4108.1

Pitari G, Ackerman A, Adams P, et al (2001) Aerosols, their Direct and Indirect Effects. Clim Chang 2001 Sci Basis Contrib Work Gr I to Third Assess Rep Intergov Panel Clim Chang 5:289-348

Prell WL (2011) Variation of monsoonal upwelling: A response to changing solar radiation

Ramanathan V, Chung C, Kim D, et al (2005) Atmospheric brown clouds: Impacts on South Asian climate and hydrological cycle. Proc Natl Acad Sci. doi: 10.1073/pnas.0500656102

Ramanathan V, Crutzen PJ, Kiehl JT, Rosenfeld D (2001) Atmosphere: Aerosols, climate, and the hydrological cycle. Science (80- ) 294:2119 - 2124. doi: 10.1126/science.1064034

Rotstayn LD, Lohmann U (2002) Tropical rainfall trends and the indirect aerosol effect. J Clim. doi: 10.1175/1520-0442(2002)015<2103:TRTATI>2.0.CO;2 
monsoon using CMIP5 coupled models. J Clim 26:7662-7675. doi: 10.1175/JCLI-D-1200694.1

Sharmila S, Joseph S, Sahai AK, et al (2015) Future projection of Indian summer monsoon variability under climate change scenario: An assessment from CMIP5 climate models. Glob Planet Change 124:62-78. doi: 10.1016/j.gloplacha.2014.11.004

Shiogama H, Stone DA, Nagashima T, Nozawa T, Emori S (2012) On the linear additivity of climate forcing-response relationships at global and continental scales Int. J Climatol $33: 2542-2550$

Smith DM, Murphy JM (2007) An objective ocean temperature and salinity analysis using covariances from a global climate model. J Geophys Res Ocean. doi: 10.1029/2005JC003172

Song F, Zhou T, Qian Y (2014) Responses of East Asian summer monsoon to natural and anthropogenic forcings in the 17 latest CMIP5 models. Geophys Res Lett. doi: 10.1002/2013GL058705

Sun Y, Ding Y, Dai A (2010) Changing links between South Asian summer monsoon circulation and tropospheric land-sea thermal contrasts under a warming scenario. Geophys Res Lett 37:1-5. doi: 10.1029/2009GL041662

Sutton RT, Dong B, Gregory JM (2007) Land/sea warming ratio in response to climate change: IPCC AR4 model results and comparison with observations. Geophys Res Lett 34:2-6. doi: 10.1029/2006GL028164

Tanaka HL, Ishizaki N, Kitoh A (2004) Trend and interannual variability of Walker, monsoon and Hadley circulations defined by velocity potential in the upper troposphere. Tellus, Ser A Dyn Meteorol Oceanogr 56:250-269. doi: 10.1111/j.1600-0870.2004.00049.x

Tao S, Chen L. (1987) A review of recent research on the East Asian summer monsoon in China. In:Chang,C.-P.,Krishnamurti, T.N. (Eds.), Monsoon Meteorology. Oxford University Press, New York, pp. 60-92. 
712 Tian F, Dong B, Robson J, Sutton R (2018) Forced decadal changes in the East Asian summer monsoon: the roles of greenhouse gases and anthropogenic aerosols. Clim Dyn 51:3699-3715. doi: 10.1007/s00382-018-4105-7

Timmermann A, Oberhuber J, Bacher A, et al (1999) Increased El Nino frequency in a climate model forced by future greenhouse warming. Nature. doi: 10.1038/19505

Tong HW, Chan JCL, Zhou W (2009) The role of MJO and mid-latitude fronts in the South China Sea summer monsoon onset. Clim Dyn 33:827-841. doi: 10.1007/s00382-0080490-7

Trenberth KE, Shea DJ (2006) Atlantic hurricanes and natural variability in 2005. Geophys Res Lett 33:1-4. doi: 10.1029/2006GL026894

Ueda H, Iwai A, Kuwako K, Hori ME (2006) Impact of anthropogenic forcing on the Asian summer monsoon as simulated by eight GCMs. Geophys Res Lett 33:20-23. doi: 10.1029/2005GL025336

Vecchi GA, Soden BJ (2007) Global warming and the weakening of the tropical circulation. J Clim. doi: 10.1175/JCLI4258.1

Walters D, Boutle I, Brooks M, et al (2017) The Met Office Unified Model Global Atmosphere 6.0/6.1 and JULES Global Land 6.0/6.1 configurations. Geosci Model Dev. doi: 10.5194/gmd-10-1487-2017

Wang B, Huang F, Wu Z, et al (2009) Multi-scale climate variability of the South China Sea monsoon: A review. Dyn. Atmos. Ocean.

Wang Z. \& Qian Y. (2009) The relationship of land-ocean thermal anomaly difference with mei-yu and South China Sea summer monsoon Adv. Atmos. Sci. 26: 169. doi: $10.1007 / \mathrm{s} 00376-009-0169-y$

Wang B, Yim SY, Lee JY, et al (2014) Future change of Asian-Australian monsoon under RCP 4.5 anthropogenic warming scenario. Clim Dyn. doi: 10.1007/s00382-013-1769-x 
anomalous anticyclone is established during El Niño development. J Clim. doi: 10.1175/1520-0442(2002)015<3252:PEATPI>2.0.CO;2

Wang C (2004) A modeling study on the climate impacts of black carbon aerosols. J Geophys Res Atmos. doi: 10.1029/2003jd004084

Wen Z, Huang R, He H, and Lan G (2006) The influences of anomalous atmospheric circulation over mid-high latitudes and the activities of 30-60d low frequency convection over low latitudes on the onset of the South China Sea summer monsoon. Chin. J. Atmos. Sci., 30, 952-964.

Wu G, Liu Y, He B, et al (2012) Thermal controls on the asian summer monsoon. Sci Rep 2:1-7. doi: 10.1038/srep00404

Wu S, and Liang J (2001) An index of South China Sea summer monsoon intensity and its characters. Chin. J. Trop. Meteor., 17, 337-344.

Xie X, Wang H, Liu X, et al (2016), Distinct effects of anthropogenic aerosols on the East Asian summer monsoon between multidecadal strong and weak monsoon stages, J. Geophys. Res. Atmos., 121, 7026- 7040, doi:10.1002/2015JD024228.

Yao Y, and Qian Y (2001) A study on the South China Sea monsoon index and the relationship between the index and regional rainfalls of China. J. Nanjing Uni., 37, 781788

Ye J, Li W, Li L, Zhang F (2013) "North drying and south wetting" summer precipitation trend over China and its potential linkage with aerosol loading. Atmos Res 125-126:1219. doi: 10.1016/j.atmosres.2013.01.007

Yeh SW, Kug JS, Dewitte B, et al (2009) El Nĩo in a changing climate. Nature 461:511-514. doi: 10.1038/nature08316

Zhang L, Li T (2016) Relative roles of anthropogenic aerosols and greenhouse gases in land and oceanic monsoon changes during past 156 years in CMIP5 models. Geophys Res Lett. doi: 10.1002/2016GL069282 
764 Zhou T, Gong D, Li J, Li B (2009) Detecting and understanding the multi-decadal variability 765 of the East Asian Summer Monsoon - Recent progress and state of affairs, Meteorol. $766 \quad$ Z., $18,455-467$.

767 Zhou W, Chan JCL (2005) Intraseasonal oscillations and the South China Sea summer 768 monsoon onset. Int J Climatol 25:1585-1609. doi: 10.1002/joc.1209

769 Zhou W, Chan JCL. ENSO and the South China Sea summer monsoon onset[J]. 770 International Journal of Climatology, 2010, 27(2):157-167. doi : 10.1002/joc.1380

771 Zhu Y, Wang H, Zhou W, Ma J (2011) Recent changes in the summer precipitation pattern 772 in East China and the background circulation. Clim Dyn 36:1463-1473. doi: $773 \quad 10.1007 / \mathrm{s} 00382-010-0852-9$ 


\begin{tabular}{|c|c|c|c|}
\hline \multicolumn{2}{|c|}{ Experiment } & Ocean & Radiative Forcing \\
\hline & & Relax to PD mean 3D & Climatological PD (1994-2011) \\
\hline & & ocean temperature and & greenhouse gases (GHG) and \\
\hline \multirow[t]{5}{*}{ E0 } & Relaxation run & salinity to diagnose & anthropogenic aerosol (AA) precursor \\
\hline & & climatological temperature & emissions. The GHG and AA forcing \\
\hline & & and salinity flux correction & after 2006 are from RCP4.5 scenario \\
\hline & & climatological temperature & Climatological EP GHG (1964-1981) \\
\hline & Early period & & \\
\hline \multirow[t]{4}{*}{ EP } & & and salinity flux corrections & and EP AA(1970-1981) precursor \\
\hline & & from relaxation run & emissions \\
\hline & Present day all & & \\
\hline & & & Climatological PD GHG and PD AA \\
\hline \multirow[t]{4}{*}{ PD-ALL } & forcing & same as above & \\
\hline & & & precursor emissions \\
\hline & experiment & & \\
\hline & Present day GHG & & Climatological PD GHG and EP AA \\
\hline \multirow[t]{3}{*}{ PD-GHG } & & same as above & \\
\hline & forcing & & precursor emissions \\
\hline & Present day AA & & Climatological EP GHG and PD AA \\
\hline \multirow[t]{2}{*}{ PD-AA } & & same as above & \\
\hline & forcing & & precursor emissions \\
\hline
\end{tabular}




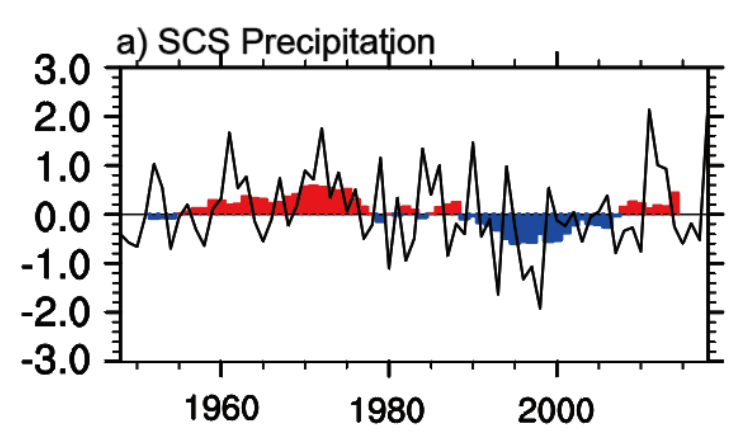

b) Precipitation \& $850 \mathrm{hPa}$ Wind
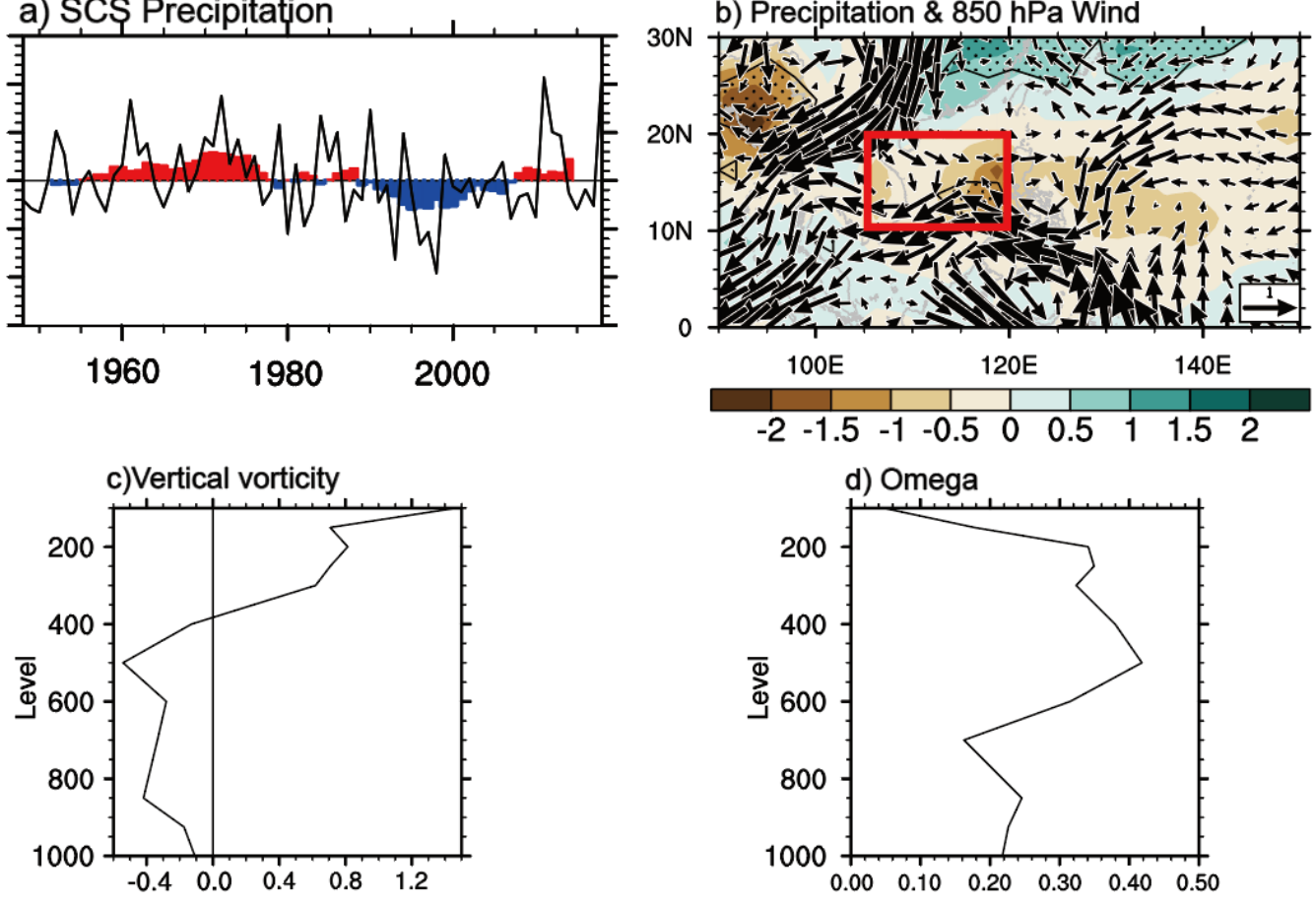

778

779 Fig.1 a) Time series (line) and 9 years moving mean (color bar) of (June-July-August) JJA

780 mean precipitation $\left(\mathrm{mm}\right.$ day $\left.{ }^{-1}\right)$ over the South China Sea region $\left(10^{\circ} \mathrm{N}-20^{\circ} \mathrm{N}, 105^{\circ} \mathrm{E}-120^{\circ} \mathrm{E}\right)$

781 based on NOAA_PREC data set. b)-d) changes between present day (1994-2011) and 782 early period (1964-1981).

783 b) Precipitation (mm/day) of NOAA_PREC and $850 \mathrm{hPa}$ wind $(\mathrm{m} / \mathrm{s})$ of NCEP reanalysis.

784 Changes of precipitation in slash regions are statistically significant at the $10 \%$ level using

785 a two-tailed Student's t-test.

786 c) Vertical profile of vorticity $\left(10^{-6 / s}\right)$ over the SCS region, d) profile of vertical velocity

787 (Omega, $\mathrm{hPa} / \mathrm{s}$ ) in pressure coordinate over the SCS. Red box highlights the SCS region. 
a) Prec (GOML2)
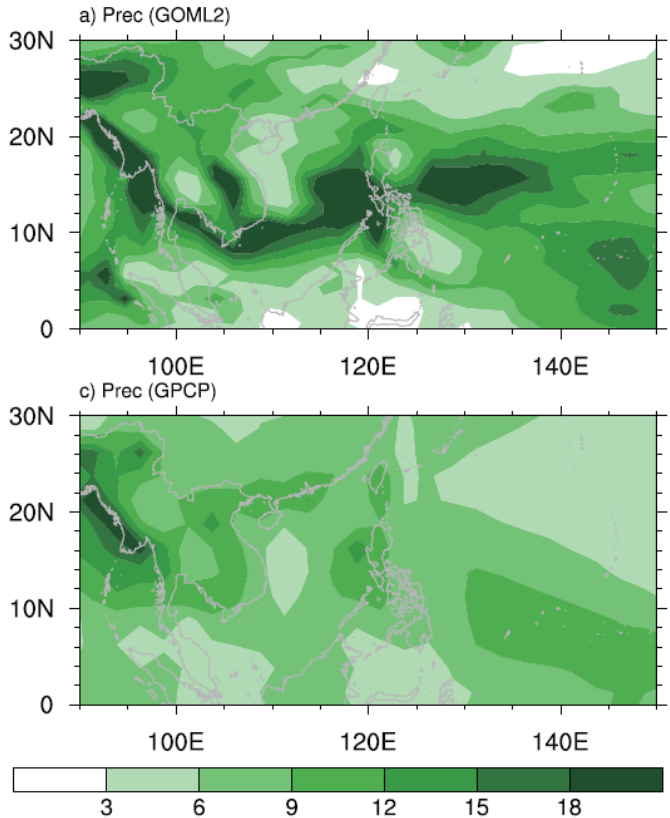

b) SLP \& $850 \mathrm{hPa}$ wind (GOML2)
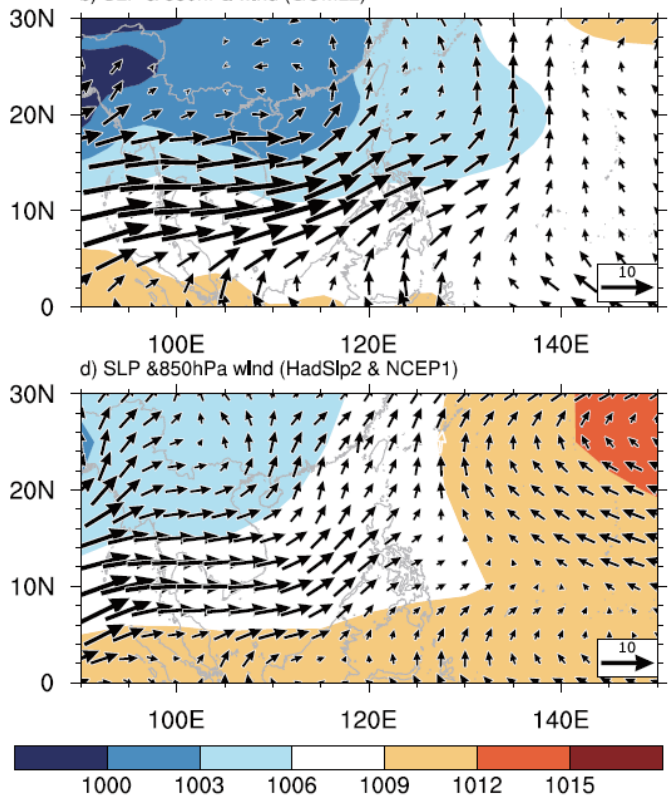

789

Fig.2 Present day (1994-2011) climatological precipitation (mm/day), sea level pressure

791 (hPa), and 850hPa wind(m/s) in JJA. a) and b) GOML2 simulation.

792 
a) Prec, $500 \mathrm{hPa}$ Omega $\& 850 \mathrm{hPa}$ Wind (GHG \& AA)
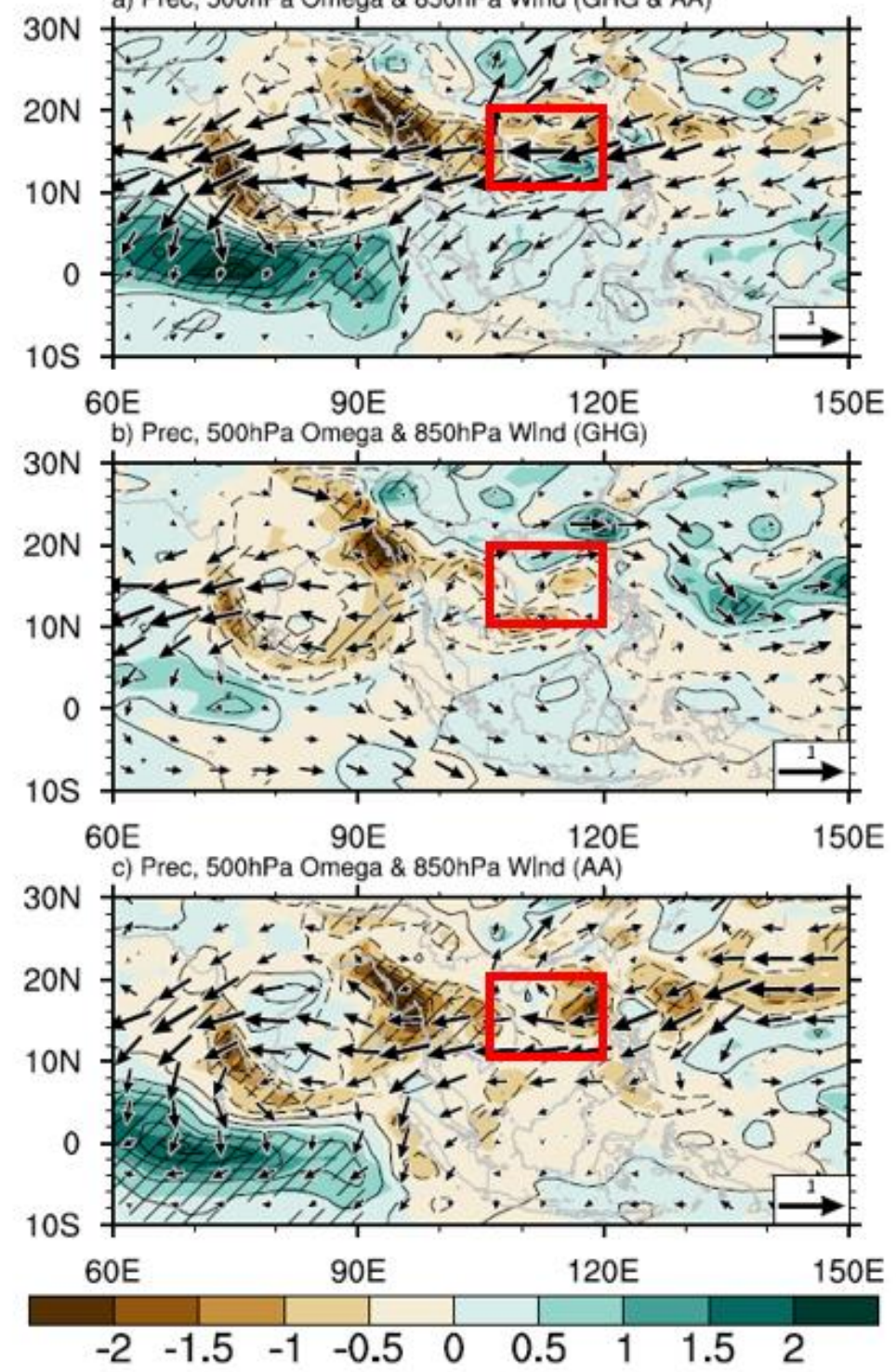

795 Fig. 3 Simulated changes of precipitation (shade, mm/day), 500hPa Omega (contour,

$7960.01 \mathrm{~Pa} / \mathrm{s}$ ) and $850 \mathrm{hPa}$ wind (vector, $\mathrm{m} / \mathrm{s}$ ) in JJA. a) Response to anthropogenic forcing

797 (PD-ALL minus EP), b) response to GHG forcing (PD-GHG minus EP), and c) response to

798 AA forcing (PD-AA minus EP) Changes of precipitation in slash regions are statistically

799 significant at the $10 \%$ level using a two-tailed Student's t-test. Red box highlights the SCS 800 region. 

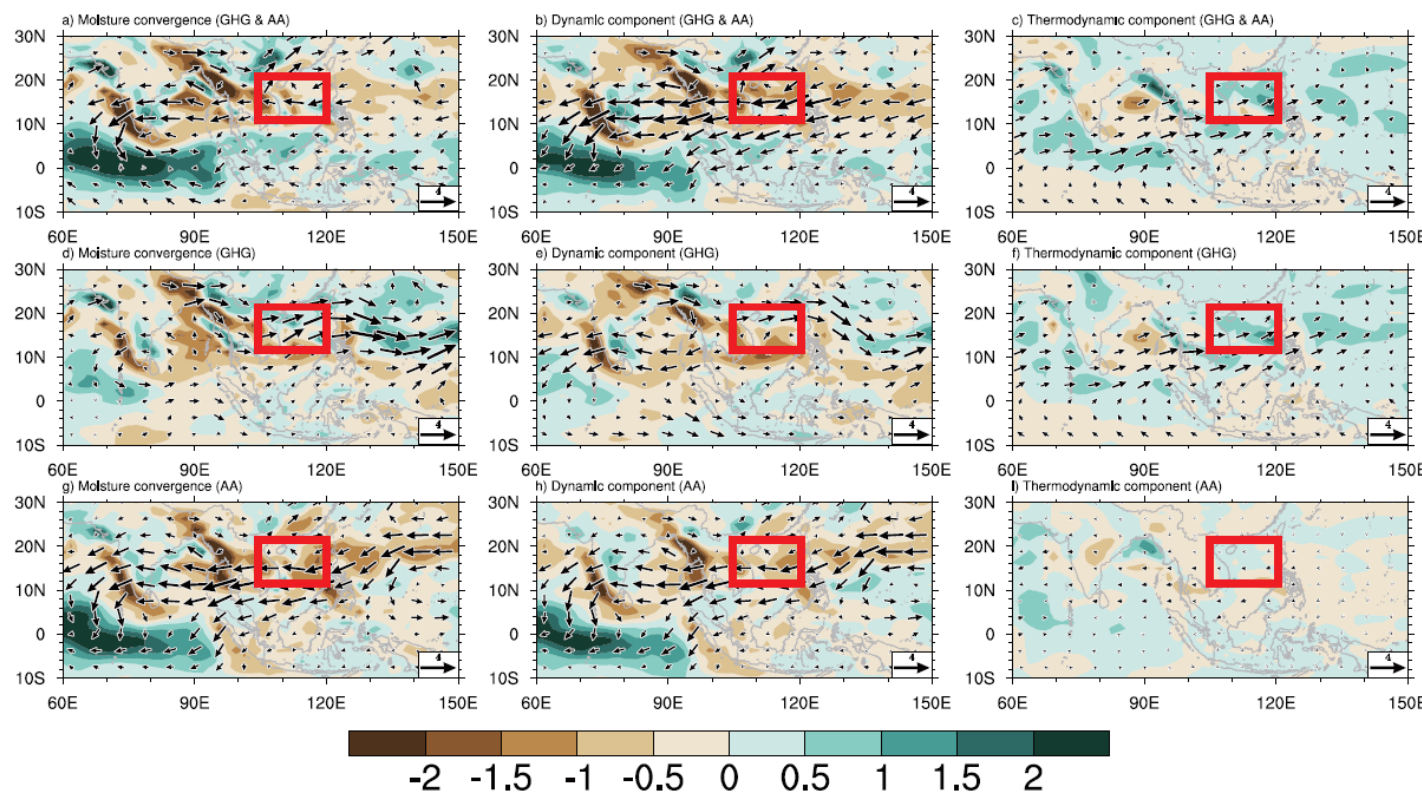

802 Fig.4. Simulated changes of vertically integrated moisture flux transport $\left(\mathrm{kg} / \mathrm{m}^{*} \mathrm{~s}\right)$ and its

(b, e, h) dynamic components related to changes in circulation. 

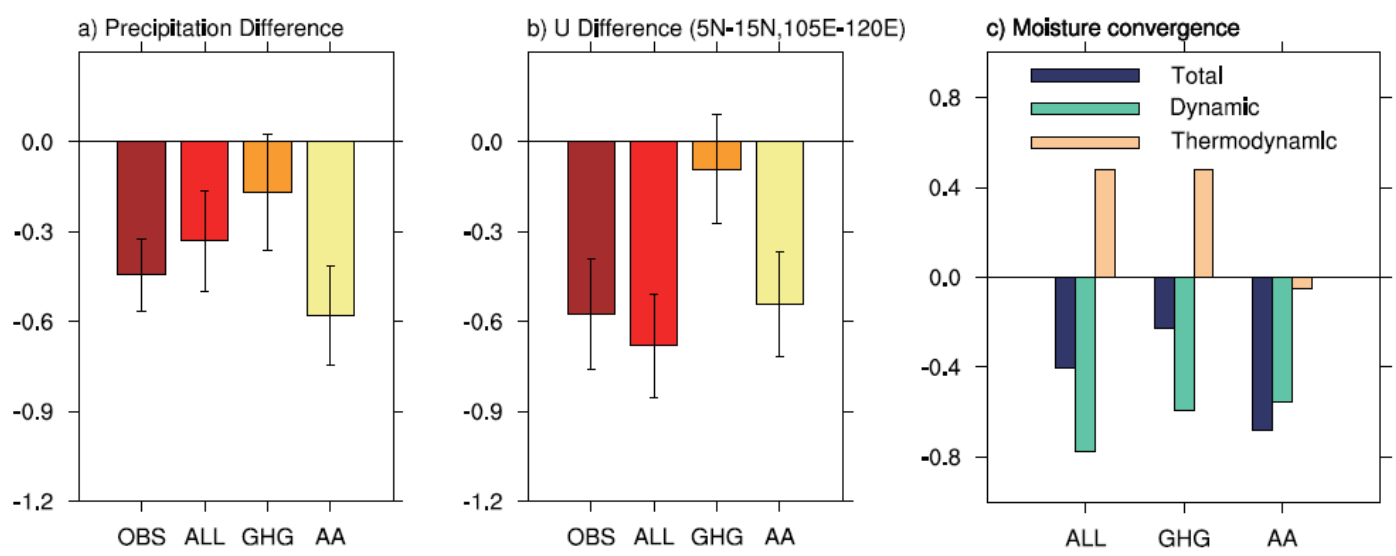

Fig.5 a) precipitation (mm/day) change between $P D$ and EP in observations

813 (NOAA_PREC), all forcing, GHG forcing and AA forcing over the SCS region $\left(10^{\circ} \mathrm{N}-\right.$

$\left.81420^{\circ} \mathrm{N}, 105^{\circ} \mathrm{E}-120^{\circ} \mathrm{E}\right)$ in $\mathrm{JJA}$.

815 b) zonal wind $(\mathrm{m} / \mathrm{s})$ change between PD and EP in observations (NCEP reanalysis 1 ), all 816 forcing, GHG forcing and AA forcing over south SCS region $\left(5^{\circ} \mathrm{N}-15^{\circ} \mathrm{N}, 105^{\circ} \mathrm{E}-120^{\circ} \mathrm{E}\right)$ in 817 JJA. The error bars indicate the standard errors of the mean difference。

818 c) simulated change of vertically integrated moisture transport convergence (blue, $\mathrm{mm} /$ day) 819 between PD and EP in all forcing, GHG forcing and AA forcing over SCS region $\left(10^{\circ} \mathrm{N}-\right.$ $82020^{\circ} \mathrm{N}, 105^{\circ} \mathrm{E}-120^{\circ} \mathrm{E}$ ) in JJA. Green bars and yellow bars are the same as blue bars but for 821 dynamic component and thermodynamic component of moisture convergence. 
a) Velocity_potential \& divergent wind $(850 \mathrm{hPa})$

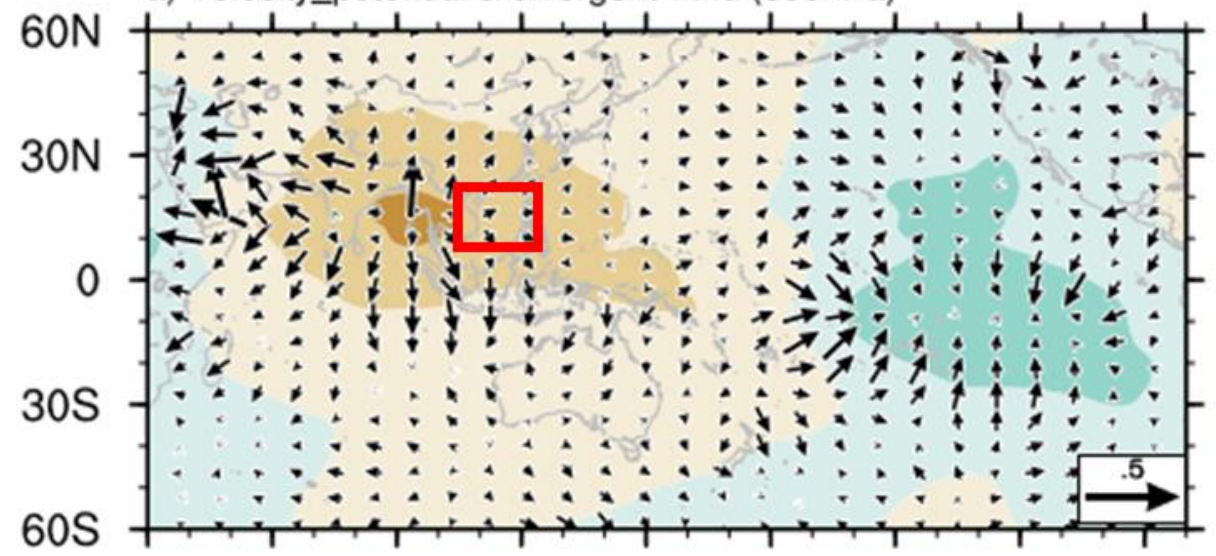

$30 E$ 60E 90E 120E 150E 180 150W 120W 90W

b) Velocity_potential \& divergent wind $(200 \mathrm{hPa})$

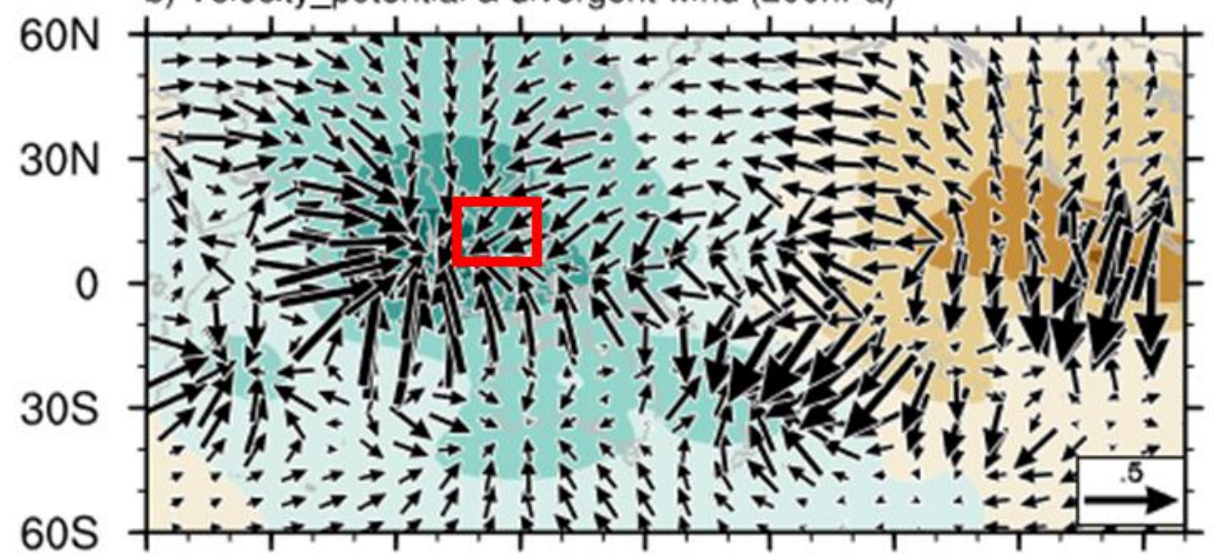

30E 60E 90E 120E 150E 180 150W 120W 90W

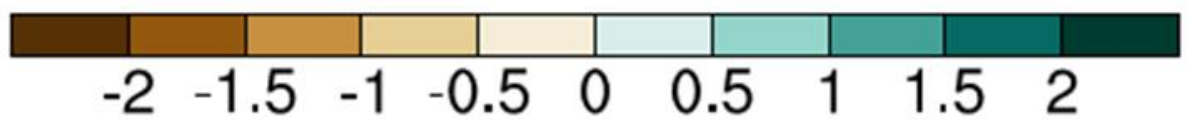

a) at $850 \mathrm{hPa}$, 
a) Precipitable water (GHG)

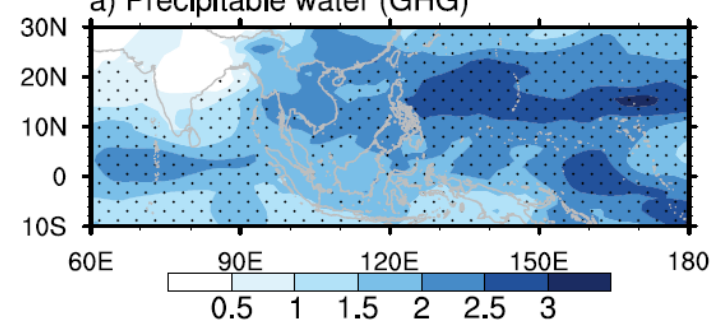

c) Clear_sky_LW (GHG)

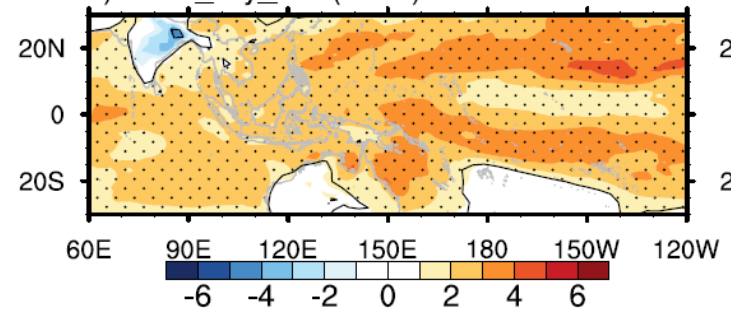

b) SST (GHG)

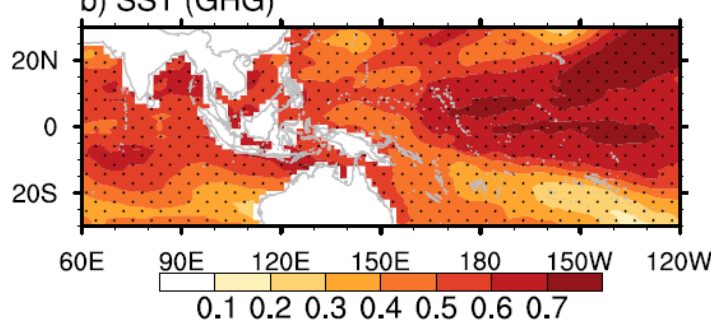

d) CRE LW (GHG)

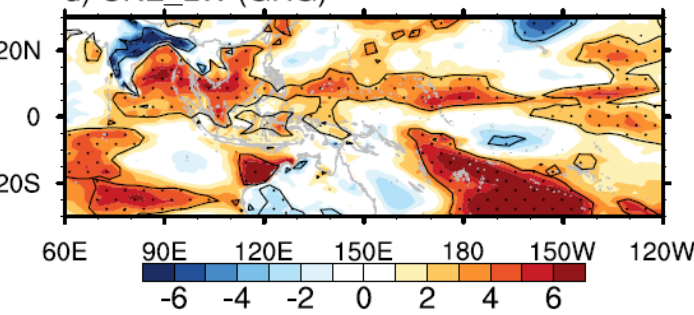

Fig.7 Simulated changes in JJA between PD and EP in response to GHG forcing. a)

832 precipitable water $\left(\mathrm{kg} / \mathrm{m}^{2}\right)$, b) sea surface temperature $\left.\left({ }^{\circ} \mathrm{C}\right), \mathrm{c}\right)$ surface clear sky net

833 longwave radiation $\left(\mathrm{W} / \mathrm{m}^{2}\right)$, and d) cloud radiative effect of longwave radiation $\left(\mathrm{W} / \mathrm{m}^{2}\right)$.

834 Radiations are positive downward. Dot regions are statistically significant at the $10 \%$ level 835 using a two-tailed Student's t-test. 

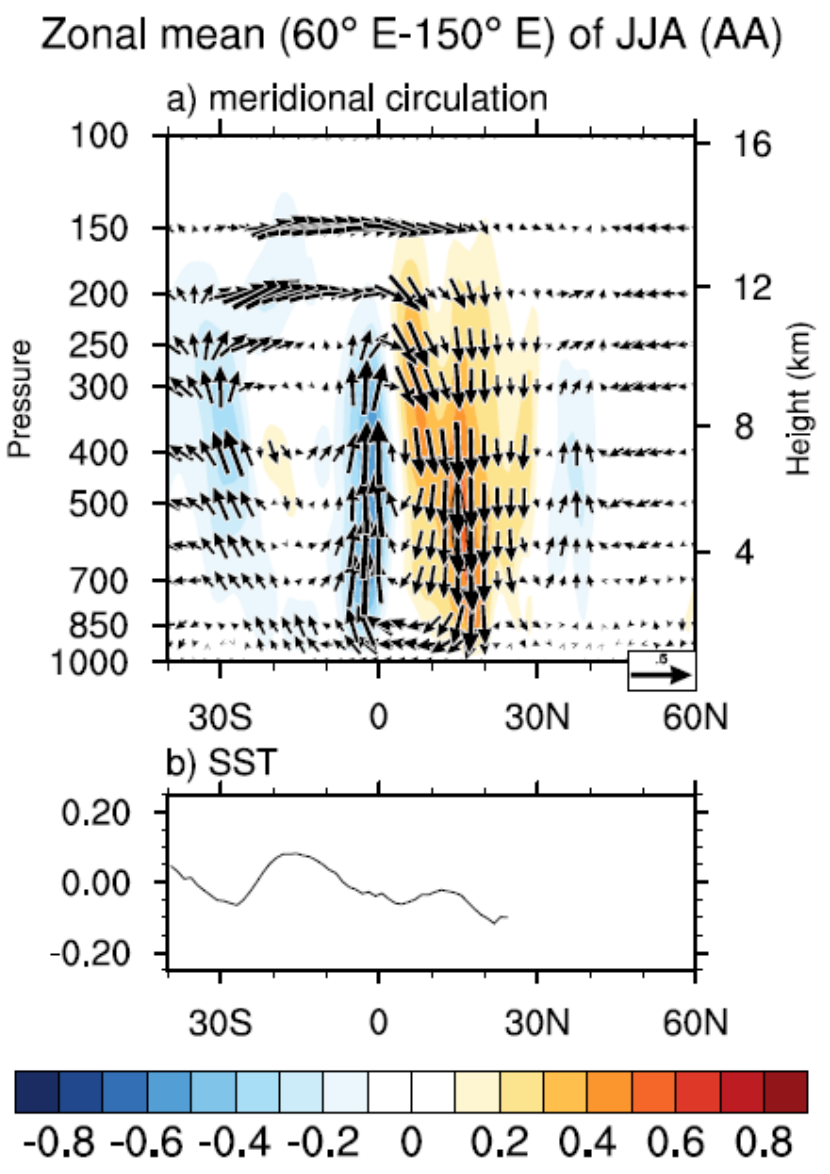

837

838 Fig.8 Simulated changes in JJA between PD and EP in response to AA forcing. a) zonal

839 mean meridional circulation(vector) and vertical velocity(contour). Unit of meridional wind:

$840 \mathrm{~m} / \mathrm{s}$, unit of vertical wind :0.01Pa/s.

841 b) zonal mean sea surface temperature $\left({ }^{\circ} \mathrm{C}\right)$. 

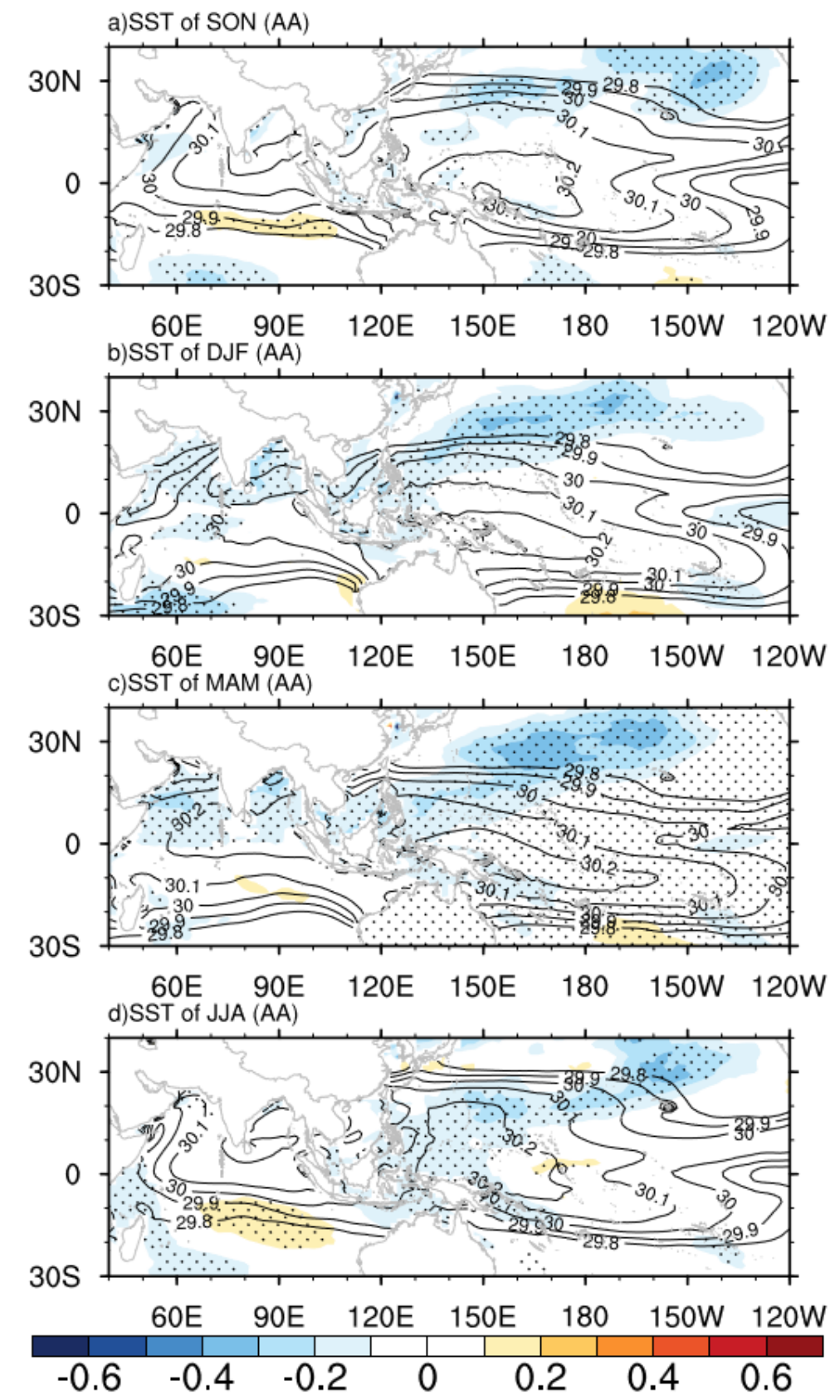

844 Fig.9 Simulated seasonal changes (color, ${ }^{\circ} \mathrm{C}$ ) in sea surface temperature between PD

845 and EP in response to AA forcing and corresponding climatology (contour, ${ }^{\circ} \mathrm{C}$ ) in the EP

846 experiment. a) boreal autumn (SON), b) winter (DJF), c) spring (MAM), and d) JJA. Dot

847 regions are statistically significant at the 10\% level using a two-tailed Student's t-test. 
Zoneal mean of $60^{\circ} \mathrm{E}-150^{\circ} \mathrm{E}(\mathrm{AA})$
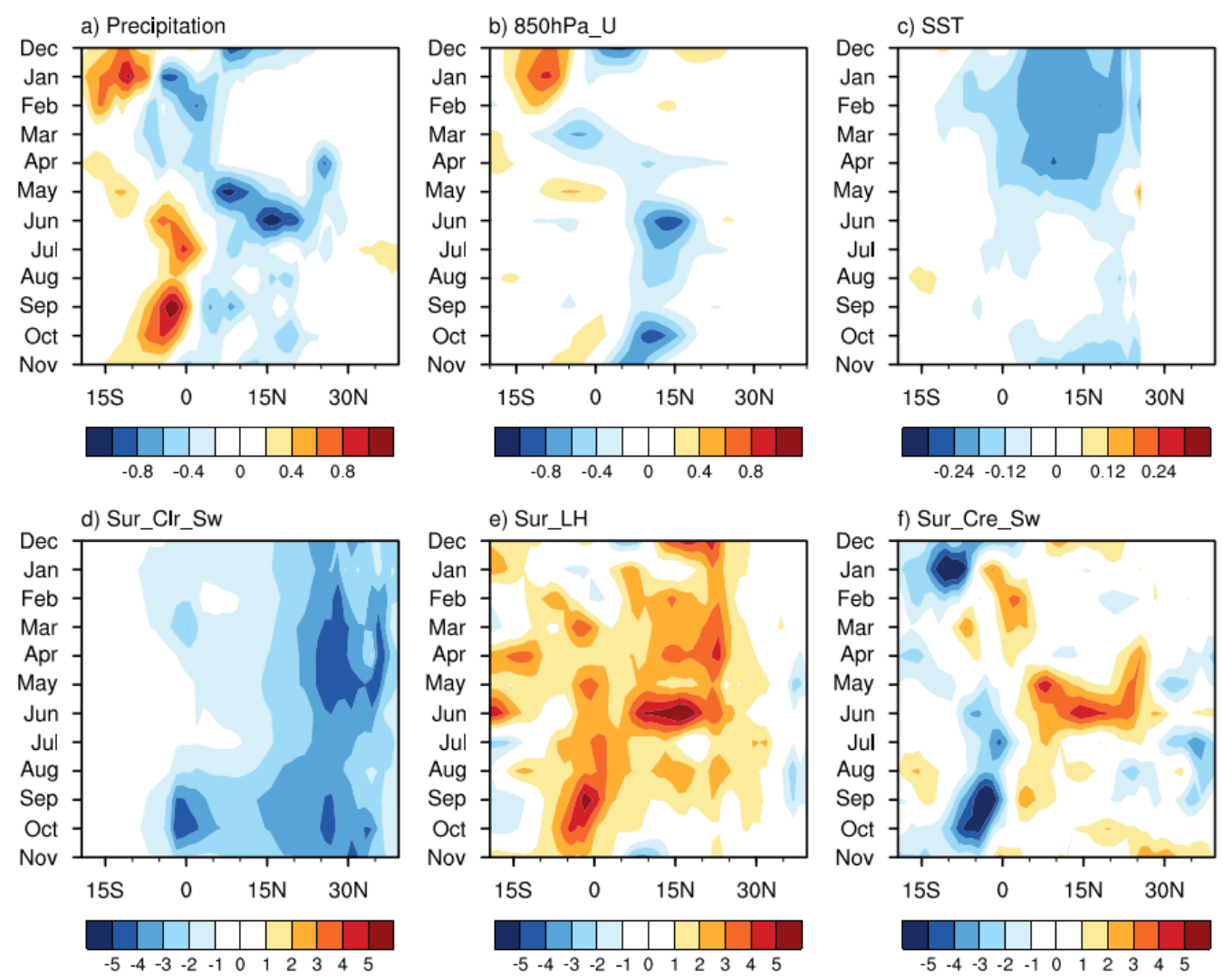

848

849 Fig.10 Simulated seasonal evolutions of zonal averaged changes over the sector $\left(60^{\circ} \mathrm{E}-\right.$

$850150^{\circ}$ E) between PD and EP in response to AA forcing. a) precipitation change $(\mathrm{mm} /$ day $)$

851 b) $850 \mathrm{hPa}$ zonal wind $(\mathrm{m} / \mathrm{s})$, c) sea surface temperature $\left.\left({ }^{\circ} \mathrm{C}\right), \mathrm{d}\right)$ surface clear sky net short

852 wave radiation, e) surface latent heat flux $\left(\mathrm{W} / \mathrm{m}^{2}\right)$, and f) surface cloud radiation effect of

853 short wave radiation $\left(\mathrm{W} / \mathrm{m}^{2}\right)$. Radiation and flux are positive downward. 

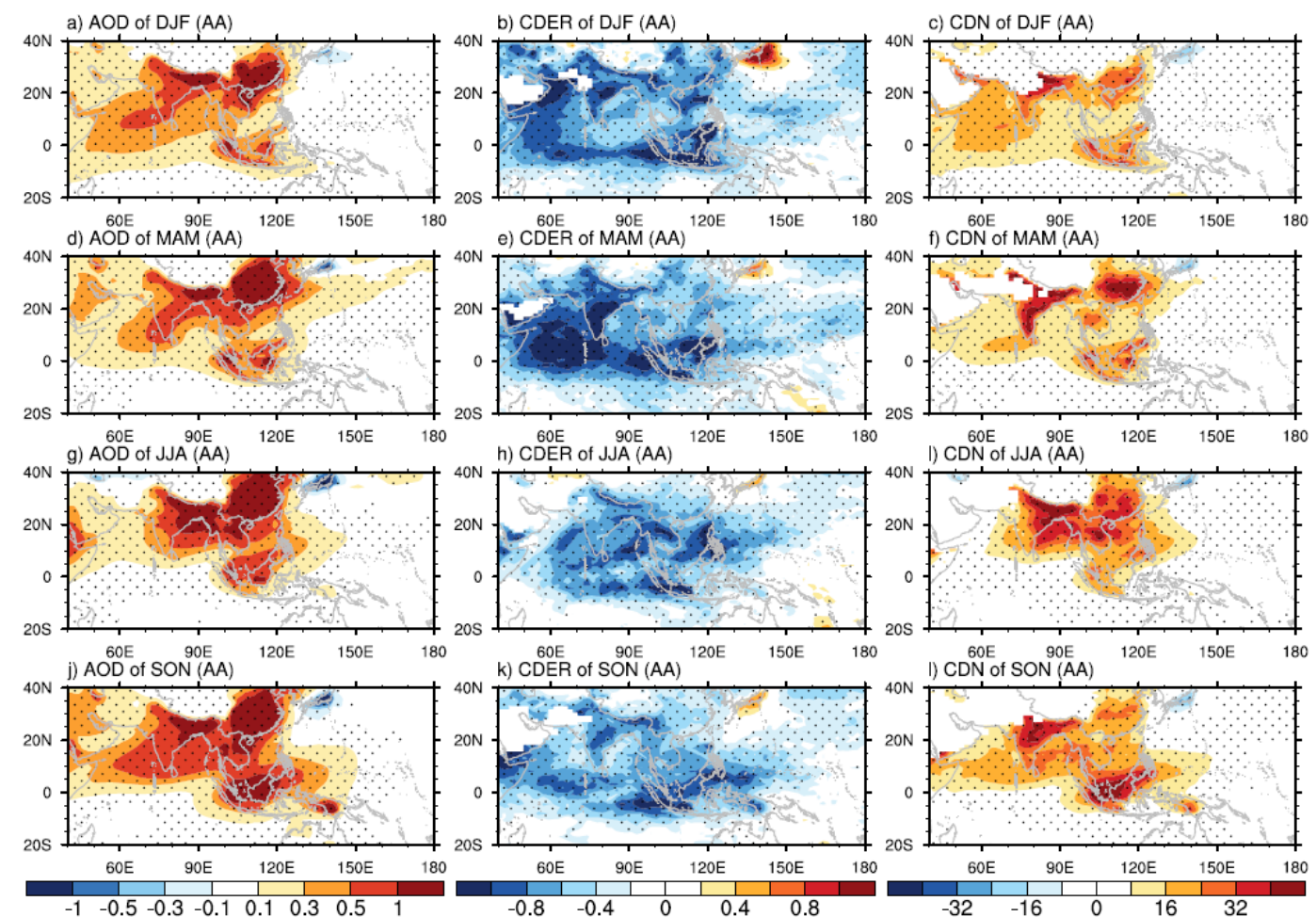

857 Fig.11 Simulated seasonal changes of aerosol optical depth (AOD, left panels, unit in 0.1)

859 droplet number (CDN, right panels, unit in $10^{9} \mathrm{~m}^{-2}$ ) between PD and EP in response to AA 